\title{
Clash of Cultures and Resistance in Selected African Plays
}

\author{
Wafa Y. Al-Khatib ${ }^{1}$ \\ ${ }^{1} \mathrm{Ph} . \mathrm{D}$ in English Literature, Language Centre, Jordan University, Amman, Jordan \\ Correspondence: Wafa Y. Al-Khatib, Ph.D in English Literature, Language Centre, Jordan University, Amman, \\ Jordan. E-mail: wafakhatib@yahoo.com
}

Received: January 1, 2019

doi:10.5539/mas.v13n5p140
Accepted: February 2, $2019 \quad$ Online Published: April 30, 2019

URL: https://doi.org/10.5539/mas.v13n5p140

\begin{abstract}
Protest African drama that appeared in Kenya and other African countries was due to the bad conditions that Africans lived during the period of colonization. This paper uses the post-colonial theory to explore how resistance in all of its armed and unarmed forms succeeded in awakening the African continent after long years of marginalization. It also tackles the clash of cultures which represents another kind of resistance, dealing with clash of cultures between the European and the African. Moreover, it will focus on the colonial discourse the colonizer relied on to assert the inability of Africans to express themselves without this discourse which the Europeans (colonial powers) invented and deliberately used to establish and deepen their domination over the black continent even after their departure.

For this purpose, the researcher will analyze two different plays written by the Kenyan playwright Ngugi Wa Thiongo, The Black Hermit and The Trial of Dedan Kimathi. The clash of two cultures will be studied in The Black Hermit, while resistance and armed resistance will be examined in The Trial of Dedan Kimathi.
\end{abstract}

Keywords: resistance, clash, cultures, oppression, African Drama

\section{Introduction}

This article discusses anticolonial resistance carried out in English language by depicting clash of cultures and resistance movements emerging in African literary works due to the social changes that took place during and after the colonial period. It is concerned with analyzing different texts written by African playwrights after independence to show their keenness on breaking with their black predecessors and confirm that they had commenced a quest for their cultural identity.

In the current work, the researcher will depict resistance and armed- resistance movements that took place in Kenya to gain independence, as these aspects will be traced in The Trial of Dedan Kimathi by Ngugi Wa Thiong'o' and Micere Mugo's. The play tries to reveal the beginning of revolution in Kenya, and how the colonizer tried to end these revolutionary movements by the arrests and the execution of the leaders. The Black Hermit by Ngugi Wa Thiong'o will be adopted to reveal the clash of cultures between the African culture and the European one as well as the loss of identity. The postcolonial theory will be applied to analyze these two selected plays.

\section{Post-Colonial Theory}

The early beginning of post-colonial theory is developed as an extension of the anti-colonial movements appeared in colonized territories all over the world. The revolutionary movements emerging in different parts of the world encouraged many critics and thinkers to articulate their underlying political logic. Edward Said, Frantz Fanon, Aimé Césaire, Gayatri Spivak, Leopold Sedar Senghor and Homi Bhabha are among the critics who paid attention to these movements, whose works helped to flesh out the relationships of this theory to imperialism, colonialism, armed and unarmed resistance, colonial discourse, nationalism and so on.

Aside from this theorization of resistance, major themes of literary post-colonial studies have revolved around identity, place, displacement and dislocation. Ashcroft asserts that "It is here that the special postcolonial crisis of identity comes into being; the concern with the development or recovery of an effective identifying relationship between self and place." (Aschcroft et al, 1989: 8)

Homi Bhabha developed the term Hybridity which is a crucial term in postcolonial theory. This term is used by Bhabha and explained by Robert Young, "hybridity becomes the moment in which the discourse of colonial authority loses its univocal grip on meaning and finds itself open to the trace of the language of the other." (1995: 
22) Young emphasizes that "Bakhtin's earlier use of the term hybridity to refer to intentional blending has been enhanced by Bhabha to identify an active moment of challenge to the dominant cultural power." (1995: 22)

According to Bhabha, all the cultures and languages are hybrid, and there is no purity of language. This belief will allow one culture to mix with other cultures without losing its specific features. Therefore, there is no pure culture or pure language.

Ngugi Wa Thiong'o explains that colonial resistance movements in Africa can be traced back to the $15^{\text {th }}$ and $16^{\text {th }}$ centuries when East Africans first took up arms against Portuguese colonists. At that time, there was no single historical work written by a Kenyan, telling of the grandeur of heroic resistance of Kenyans fighting foreign forces of exploitation and domination. In general terms, the new literary genre referred to as resistance literature emerged from this struggle later on.

The African playwrights believed in the significance of creating their counter-narrative as a way to defend their African nationality and tell the whole story of colonization and the African revolution movements from their own perspective. This awareness of the African identity came immediately after the Second World War (WWII).

After the departure of the colonizer, and sometimes during the period of colonization, colonized people carried the burden of fixing the distorted image of themselves that appeared in the canonical European works. Said's Culture and Imperialism (1992) is probably the major work that paid attention to the misrepresentation of colonized people in English novels written during the $18^{\text {th }}$ and $19^{\text {th }}$ centuries. Homi Bhabha in The Location of Culture remarks that "the main feature of colonial discourse is its dependence on the concept of "fixity" in the ideological construction of otherness" (1994: 94).

Ngugi Wa Thiong'o is probably the most associated figure with the ability of African languages and literatures to challenge imperialism. Ngugi argues, prominently in Decolonizing the Mind (1986), that African writers using the language of their colonizers announce that they detach themselves from their own culture and traditions (and of course language). Ngugi insists that the African writer should use his/her own indigenous language aside from the more direct meaning of doing so as a symbol of resistance to pass this language and the culture that it transmits down to the new generations. This importance of language is echoed by Achebe, Spivak and other writers.

Ngugi wrote his early novels in English, but later shifted to use his native language Gikuyu in all of his writings. In addition, he prominently represents African elements in his plays and novels such as drums, songs, folk costumes and so on. He remarks that using English or any other European language amounts to a kind of emphasis that Africa cannot exist without the support of Europe giving the colonizer permission to continue the domination and subjugation of the land and people, even after the end of formal colonization. Therefore, Ngugi insists African writers should follow their European predecessors who preserved and contributed to their own native languages:

African writers are bound by their calling to do for their languages what Spencer, Milton and Shakespeare did for English; what Pushkin and Tolstoy did for Russian; indeed, what all writers in world history have done for their languages by meeting the challenge of creating a literature of them. (1986:29)

Ngugi believes that all the African works of literature written before and after independence constitute an important part of the African's battle against imperialism, remarking that no one can separate politics from literature. He motivates African writers to awaken a revolutionary spirit among the common people. Ngugi argues that:

The system of education in Kenya during the period of colonization had the structure of a pyramid: a broad primary base, a narrowing secondary middle and an even narrower university apex. The imperial powers kept focusing on English language; nobody could be accepted at universities without passing the English exam. English was the official vehicle and the magic formula to colonial elitedom (1986:8).

The crucial issue of language occupied the minds of numerous African critics and thinkers. In Black Skin, White Masks, Frantz Fanon points to the importance of language "to speak means to be in a position to use certain syntax, to grasp the morphology of this or that language, but it means above all to assume a culture, to support the weight of civilization" (1986: 17). Unless we first free our tongues and our minds, we will never be able to free ourselves from the colonizer. Using the language of the colonizer means that we abandon our indigenous language, our culture and our tradition. These arguments grew out of the recognition of how thoroughly colonialism and imperialism brought colonized peoples to complete disorder, disconnecting them from their histories, their landscape, their language and their social relations.

In his etymological study of the words culture and civilization, Raymond Williams explains that "the word culture as it first emerged in German (Kultur) was used in the sense of becoming cultivated or civilized and thence as a description of the universal process of human development or civilization" (2012:10). However, the mission of the 
colonizer was not cultivating or civilizing the colonized, but controlling them. The indigenous culture is, from that perspective, an obvious and probably existential threat to the Western presence.

This gap between cultures is described by Terry Eagleton: "the rift between culture and culture is not a cultural one. It cannot be repaired simply by cultural means. It has its roots in a material history - in a world which is itself torn between empty universalism and narrow particularism, the anarchy of global market forces and those cults of local difference which struggle to resist them" (2000: 45). Whereas, Eagleton considers the clash of cultures as a political issue that appeared among different cultures. According to him, it is battle in which they must win, as the dominant power tries to impose itself over other cultures.

\section{Clash of Cultures}

The Black Hermit by Ngugi wa Thiongo, is the story of a young man, Remi, who is the first of his tribe to attend university. Remi has received his education in the schools and universities of the colonizer, and has absorbed the colonizer's language, religion and traditions. He has abandoned his wife, mother and his tribe and travelled away to the city to be a hermit. Remi himself is torn between his sense of tribalism and his sense of civilization. This struggle runs deep, as he finds it between himself, his marriage and familial relations and his greater sense of obligations to his people and the country. The overwhelming of these problems drives him into isolation as a black hermit. Nobody can forget that he is black; the blackness of his skin prevents him from achieving his goal. His exile into the city leads him to start a relationship with Jane, his new lover. However, having been convinced to return to his tribe, he has to confront his past. Imperialism succeeded in turning Africans into black shadows and silent objects, never allowing them to forget their blackness and their inferiority. Their struggle for a space from which they can speak and identify their real identities will not be given by the colonizer, but must be struggled for.

The colonial encounter in Africa created many clashes within African societies. Klima et al. (1976) confirm that "this clash is between two cultural systems, each possessing its own characteristic hierarchy of values. The elements deriving from the more advanced system appeared to be modified and differently situated in the less advanced system" (1976: 284). Furthermore, Makouta Mboukou (1965:3) argues that "Black literature is first of all, literature of combat. The writer throws himself into demands for retribution: the rights Black people have been deprived of by foreign domination must be recovered, Black people's place among the other people of the world must be demanded."(3)

After several disappointments, Remi in The Black Hermit announced that he does not want to continue his life in the city; he has discovered that he does not belong there, and; the hegemony and the hostility of the other have awaken him politically, therefore he decided to go back to his tribe, and to leave his lover Jane who couldn't understand him. The hatred for the European civilization clearly appeared, he says:

One day you will know. It's only that I am tired of this city. That's all. I hate working for these oil companies that have invaded our country. Files, files, files all day long (1968: 26).

Ngugi's Africans are either obsessed with modernity or its technology, which they do not produce, or totally reject what is modern and unfamiliar to them. The contradiction between traditional culture rooted in village life, and the modern city is appalling; and Remi, who was obsessed with modernity and city life, comes to abandon this new life and goes back to his roots. The tribal life called him back; he was unable to detach himself totally from his tribal life.

Remi in The Black Hermit is unable to maintain this balancing act and commits to only one identity at a time as follows: First, the European one and later the precolonial African one. Remi here suffers from alienation and his sense of torn between two cultures and two identities estranged him. Suddenly, he does not know if he belongs to the African culture or the European one.

Ngugi writes his play The Black Hermit within a historical context; of national liberation struggles and resistance movements against the Western imperial powers and apartheid regimes that dominated Africa for a long time. Lewis Gordon asserts that "according to Fanon, there is not an occupation of the territory and independence of persons. It is the whole country, its history, its daily pulsation that are contested, disfigured, in the hope of a definitive annihilation...from this point on, the real values of the occupied quickly acquire the habit of existing clandestinely" (1996: 102).

History of Africa has thus been variously defined. For some historians, it is coincident with the history of colonialism, and remains implicated with the conditions that produced it. African playwrights point out that the colonial relationship was a relation among societies, as each of which had its own distinctive social institutions and its own internal differences, its own culture and sub-cultures.

Ultimately, Remi the "European", in The Black Hermit discovers that he is just a tool used by the colonizer to 
extract him from his roots. Those who received their education at imperial schools and universities come to understand that they are serving those who have stolen their wealth, their land, their culture and their fortune. Once the colonized comes to know this fact, he stops believing in the European culture, and he turns back to his indigenous culture.

Remi in The Black Hermit asks: "has our nationalist fervor that gave us faith and hope in days of suffering and colonial slavery been torn to shreds by such tribal loyalties? All my life I believed in the creation of a nation" (1968:41). In doing so, Remi goes against his tribe, and starts thinking as the colonial power used to think, that way forward is to destroy the tribes, end loyalty to one tribe, convince educated people to reject their primitivism and become a developed country. Remi says: "Save them from traditions and bad customs, free them from tribal manacles". (1968:45)

From this basis, the imperial powers ultimately even succeeded in convincing Remi to adopt the ideas of the regime; he becomes the hand that helps to end tribal life in his country, which he views as a pair of manacles that enslave the people again rather than having helped free them from colonialism. Jane (The white woman) (Remi's beloved) faces Remi with the truth, saying: "I know what I want' what I am. You do not know yourself, or what you really want. Only that you like thinking yourself a delicate being, superior and so much better than anyone else." (52)

Coercive action became the tool with which Africans reinforced their sense of their identity, facilitating the start of an individual, social, political and cultural -revolution. In any state of oppression, at least a small number of the oppressed will organize their own people to resist; in such cases, identity becomes the core of the struggle. After the departure of the colonizer, Africans saw that they still have a lot of cultural, social, and political problems to deal with some more serious than during the colonial period. For instance, related problems to control of property and resources by Africans and not Europeans, without which the locus of domination would simply have shifted. Regardless, even after the end of colonization, people could not feel safe or at liberty. In The Black Hermit, Omango talks to Remi about his fears:

I fear for our country. Independence has not reduced the amount of racial tension. This affair of an Asian girl who has been ostracized by her community because she was seen going round with an African is not an isolated case. (1968: 28)

The former social and community life of Kenyans were deeply damaged by the British colonizer. The social life of any tribe or group of people depends on the entire system of traditions, beliefs and religion which enable people to know how to interact with each other. What the colonizer did was to destroy every element that fastened the relationships between individuals and the tribe or other collective groups. Forcible, coerced, or free conversion to Christianity was a major element of this destruction, and Christianity was something viewed as a curse that would kill everyone who followed it. In The Black Hermit Elder talks about Engome who has passed away, to his wife:

He was a man, oh yes

Your husband was

Before the white man stole his heart

And turned him into a Christian (7)

The colonizer under the cover of "civilizing the barbarians" tried to impose his religion over them, and this meant severing them from their history and primitive traditions. In this way, missionary campaigns that were founded in Africa during the period of colonization were not for the sake of Christianity, but a tool of hegemonic rule. The colonizer's mission was for the sake of dominating the people and exploiting the land. In order to hide their greedy purposes, the Europeans announced to the world that they are keen on civilizing and educating the Africans.

Part of African tradition is the belief in the holiness of the tribe. To start suspecting the intentions of their tribes and stop believing in tribalism destroyed the trust among African people, along with their way of living and in some cases their lives. In The Black Hermit, Omange says:

But take tribalism for instance. Since independence, tribalism and tribal loyalties seem to have increased. And even the leaders who were the supporters of the Africanist party are the very ones who are encouraging these feelings. Do you think these people would pass an effective piece of legislation when it would touch the very taproot of their power? (29)

Haidar Eid, in his article "Naipaul's A Bend in the River and Neo-colonialism as a Comparative Context," tackles the same idea when he refers to Big Man's speech as "a kind of emphasis that although the Big Man claims to have an independent state, he is still dependent upon European experts. So, when he nationalizes the business of 
foreigners, he delivers them to his experts." (2000:5) Therefore, "the liberation army opposed to the Big Man declares that we have decided to face the enemy with armed confrontation, by enemy we mean the puppet powers that be, the false Gods, the capitalist." (5)

As long as the natives suspect the intentions of the local and traditional governing structures and the people within them who will help the colonizer keep his domination over the land, the natives will continue to face it by revolution. The leaders of the Africanist parties who inherited power after independence were concerned with their own interests and their positions, regardless of the interests of their country. Imperialism has succeeded in planting discrimination among different tribes and religions in Africa. Ngugi in Decolonizing the Mind confirms that:

The biggest weapon wielded and actually daily unleashed by imperialism against that collective defiance is the cultural bomb. The effect of a cultural bomb is to annihilate people's belief in their names, in their languages, in their environment, in their heritage of struggle, in their unity, in their capacities and ultimately in themselves. (1986:3)

In this context, the main concern of the majority of African thinkers has been to reveal the destructive role the white man played in Africa, and how the most important mission was not to civilize the savages but to force them to abandon their religion, traditions and language. In both Decolonizing the Mind: The Politics of Language in African Literature (1986) and Moving the Centre: The Struggle for Cultural Freedom (1993), Ngugi makes language fungible with culture. He believes that both language and culture are the blueprints of identity and values for a nation or a people:

Language as culture is the collective memory bank of a people's experience in history. Culture is almost indistinguishable from the language that makes possible its genesis, growth, banking, articulation and indeed its transmission from one generation to another. (1986:15)

So, to abandon an indigenous language means that people are ready to forget their history and their culture and to lose their collective memory, the memory that they share with their people. Ngugi believes that culture can only be transmitted through its native language. Edward Said is a critic who did not use his indigenous language in his works. For him, to use Arabic meant giving up on the possibility of convincing Western people of his argument, and losing that space to defend oppressed people in Palestine and around the world. Writing within the colonizer's language facilitates his mission, and writing in Arabic hampers it. For him to speak for the oppressed people is more important than the vehicle he uses.

The sinister role of Christianity was just a lie used to convince the world of the holiness of the mission of the colonizer in Africa. Religion in Africa is deeply rooted in the African culture. Therefore, to ruin their religion is a challenging mission that will enable the imperial powers to control the Africans. This appears clearly in The Black Hermit when the Elder addresses Nyobi, Remi's mother, he says:

And even now, four full years after independence,

They had not discovered the lie,

You still call yourself a Christian (1968:10).

The colonization of Africa coincided and was intertwined with the expansion of Christian missionary activity there. Evidence suggests that while many missionaries opposed the harsher aspects of colonialism, they were supportive of the colonization of African countries in general. The resistance movements that started in Africa before independence, continued even after independence, with a sustained focus on stopping colonial powers and their followers from achieving their mission. In The Black Hermit, leader says: "Look at our country since independence. Where is the land? Where is the food? Where are the schools for our children?" (1968:13)

The quest for full freedom comes with heavy challenges and obligations, resisting the encroachment of the former imperial powers; restoring languages and cultures; uncovering buried history and collective memory. Indeed, restoring the role, importance, and integrity of the tribe, which in an African context has been the traditional organization of society, must be the vehicle of rebuilding it. Nyobi, Remi's mother, in The Black Hermit refers to the power of the tribe as a kind of talisman (13):

Together with power of the tribe,

to bring back Remi. (1968:13)

Remi explains to Jane, his white beloved one that he cannot resist the power of his tribe, and he can no longer stay away from his home. He says that he will starve and suffer from the new government, yet he insists on going back to his tribe. Remi says: 
When I came to the city running away from the tribe, I never knew I would ever go back. I wanted to be a hermit forever. But now they have called me back. And I must go. (48)

Remi could not ignore his tribe's call for him to come back. Remi's mother and wife asked the help of the elder people in the tribe to convince Remi to come back to his family and his tribe as well. The power of the tribe in Kenya is clear as no one can resist the power of his tribe, although some educated Africans think about the institution of the tribe in a negative way, yet they cannot resist the power of their tribes. The supernatural power of the tribe and the Western knowledge of educated Africans both needed to rebuild these cultures and societies and regain control over an objective history. Remi wants to live within his tribe, yet, at the same time he wishes that his tribe may accept the European knowledge to civilize themselves. In this sense, one may start to suspect Remi, and wonder if Remi is still an African or a black European.

The colonized tries to assimilate the colonizer because he sees the colonizer more powerful than the colonized; therefore, he will be tempted to imitate the colonizer in order to be accepted like him. In this regard, Stuart Hall and Paul du Gay explain:

Ernesto Laclau describes the constitution of a social identity as an act of power. Objectivity manages to partially affirm itself it is only by repressing that which threatens it. Derrida has shown how an identities constitution is always based on excluding something and establishing a violent hierarchy between the two resultant poles- man/women. It is the same with the black white relationship, in which white, of course, is equivalent to human being. Woman and black are thus marks in contrast to the unmarked terms of man and white. (1996:5)

Remi tried to disguise his blackness with a white mask; he wanted to forget his blackness. Remi suffers from being black, and from being an African among white people. Remi's dream to become a hermit has destroyed at the moment he discovered that the Europeans will never accept his blackness. The Black hermit, Remi, will never be able to lead a normal life within the hostility of the Europeans. Remi explained his sufferings to his beloved Jane when he told her that he is going back to his tribe and his people. Remi says:

How can be the same? How can the call for the tribe be your call? To you tribalism and colonialism, the tyranny of the tribe and the settler are an abstraction. To you, African nationalism and what it means to us who suffered under colonial rule for sixty years can only be an intellectual abstraction. (47)

Remi cannot forget the sufferings of his people under colonialism. It seems that Africans who lived under the domination of the imperial powers became more connected with their tribes. To them, tribe means Africa, tribe is their identity, and if they let it go, they will be left with a fragmented identity. Therefore, Europeans will never understand the holiness of the tribal life and the importance of living within a tribe.

This colonial discourse is seen parallel to the striking image introduced earlier, "a chain of exhausted slaves roped into one another" (1976:5), reflects the insistence on dehumanizing the natives and reveals the cruelty of the colonizer, where this hegemony inspired people to fight back and created a revolution which continued until independence. Colonial discourse is marked by the unique habit of speaking about the colonized while keeping them at a distance; the colonized voice can never be heard. This is seen again in the play when Ngugi calls the natives "a labour force of blacks" (1976:5), "black bastard" (7), reducing them to passive objects of desultory surveillance.

\section{Resistance and Armed Resistance}

Literature of resistance enables colonized peoples all over the world to narrate their own stories and to reverse what has been written before. The absence of a real definition of the term resistance opened the door for many inquiries and led critics to use the contextual approach in their treatment of the theme. Therefore, resistance literature carries the burden of explaining the historical development of colonial conditions and post-colonial liberation struggle.

Barbra Harlow in her book Resistance Literature (1987) argues that resistance literature is "a particular development of colonial category of literature that emerged significantly as part of the organized national liberation struggles and resistance movements in Africa, Latin America and the Middle East" (80). While on the other hand, Patricia B. Arinto explains that "resistance literature seeks to again inscribe the history of the third world which has been distorted, misrepresented or all together ignored in Western discourse. Thus, resistance literature shows how imperialism has undermined the people's consciousness in its destruction not only of political, social and economic institutions but also of cultural institutions." (1991: 59)

The Trial of Dedan Kimathi (1976), by Ngugi Wa Thiong'o and Micere Cithae Mugo narrates the Kenyan armedresistance against the imperial powers. The two playwrights do not want to re-create the trial of Dedan Kimathi, 
the leader of Mau Mau movement, realistically. Instead, the play consists of connected episodes. The scenes in the courtroom with other scenes depict the Kenyan history of the preceding two hundred years, scenes of Kenyan people attempting to help Kimathi escape, scenes of Kimathi's interactions with guerrillas, scenes of Kimathi in prison and scenes of his torture. The reader can notice Gikuyu songs and dances which are used in the play as an emphasis on the African resistant spirit. The Trial of Dean Kimathi also looks back at Africa's great history before colonialism. In this play, Ngugi tries to help his people escape from the bad influence of oppression. The play deals with the role that the historical resistance leader Kimathi played in the movement until he was convicted of terrorism and executed by the colonial government in 1957.

The opening scene of The Trial of Dedan Kimathi introduces the reader to a colonized land and people and how the colonizer underestimates them. Post-colonial theory pays great attention to the colonial subject, The Trial of Dedan Kimathi is concerned with the way the colonizer views the natives: as objects to be set aside, voiceless and without the right to agree or disagree. "The courtroom is overcrowded. Africans squeeze around one side, seated on rough benches. Whites occupy more comfortable seats on the opposite sides."(1976: 3) In this scene, the hegemony of the colonial power appeared clearly. The Africans are denied of their basic rights to sit as humans, while Europeans have given a proper place to sit. No space is given to the colonized even to sit; the silenced natives are subjected to servitude and to marginalization.

Indeed, European colonialism in Africa was characterized by a systematic dehumanization of the Africans, forcing them into a role and space contrasting European humanity. It is a kind of direct dehumanization to the natives, in which there were two groups one humanized white and one dehumanized black. In his book Orientalism, Edward Said places the colonizer and the colonized at the opposite ends of a hierarchical system. Said explains that "for imperialists like Balfour, the oriental, like the African, is a member of a subject race and not exclusively inhabitant in a geographical area" (1978: 92).

The dominant culture tries to marginalize the dominated culture by convincing the natives that they are created to be slaves and that they should accept their enslavement rather than resist it. In The Trial of Dedan Kimathi, we come to see a woman walking across the stage. She is between thirty and forty years of age, a mother and a fighter all in one. This Woman explains the whole situation of enslavement:

Our own food eaten, and leftovers thrown to us-in our own land, where we should have the whole share. We buy food from our own forests; sweat on our own soil for the profit of our oppressors. Kimathi's teaching is: unite, drive out the enemy and control your own riches, enjoy the fruit of your sweat. (18)

This African woman with her Kanga cloth wrapped around her upper body over her simple frock stands bravely in the court, and the audience can notice that she is moving straight into the mouth of a gun. This woman is proud of her origin, she believes in the power of herself and her people. She is proud of her African costume; it empowers her to face the colonizer. Like African men, African women can face death and can defend their country and their culture.

Ngugi considers literature to be a central element on both sides of this aspect of the struggle for cultural domination/liberation, and believes in the importance of indigenous literature to organize resistance. In Writers in Politics, Ngugi explains that "a culture embodies a community's structure of values, the basis of their world outlook, and how they see themselves and their place in the universe and in relation to other communities."(1981: 9)

In the character of Kimathi, Ngugi and Mugo present a hero of liberation, a symbol of relentless struggle and unyielding force and an inspirational figure who leads the masses to resist. The leader in the play cries out:

Leader: Away with oppression

Unchain the people

Crowd: Away with oppression

Unchain the people (5)

Kimathi: Break these chains. Unchain my heart, my soul! Unchain four centuries of chains. Kenya, our dearly bought, fought for motherland. (44)

The people chant the same words, repeating them and taking on a mass identity. The Africans start behaving as one person, they share the same sufferings and longings to get rid of the colonizer. Therefore, they constitute one mass identity that can face the hegemony of the colonizer. This mass identity is created due to the sufferings, oppression and slavery that all the Africans share. They start talking as one man, one voice and one throat. They roar loudly in both English and Gikuyu language. Interestingly, this merging of individuals into a mass entity is in 
some sense paralleled by their dehumanization by the imperial power:

Phase 11: A chain of exhausted slaves, roped onto one another, drag themselves through the auditorium, carrying heavy burdens, ending up on the stage. They row a boat across the stage, under heavy whipping. (1976: 5)

Mass resistance is a more contemporary phenomenon. The cruelty of the colonizer and the dehumanization that the mass faces every day encourage the masses to rebel against those who dominated, subjugated and dehumanized them. In the Trial of Dedan Kimathi the crowd keeps singing: "rally round the sun, make a new earth." (1976:4) David Jefferess points to Mahatma Gandhi's social and political thought to "provide insight into the ways in which resistance can be imagined and articulated alternatively to dominant theories of resistance within post-colonial studies" (2008: 96). Jefferess explains that "Gandhi confirms that resistance does not signify the insurgency of the 'oppressed' against the 'oppressor', but the transformation of the material and discursive structures that maintain oppression.” (2008:2)

According to Jefferess, "Fanon's theory of anti-colonial violence emphasizes resistance as a mass cultural project and argues that freedom cannot be achieved by the eviction of foreign rule, but by the transformation of structure of inequality and the narratives that legitimize colonial power" (2008:3). By the arrest and execution of Dedan Kimathi on the $18^{\text {th }}$ of February 1957, the Mau Mau movement was stopped, but the armed resistance against the colonial power never stopped until Kenya gained its independence in 1960.

In spite of his death, Kimathi stands among his people as a symbol of revolution and liberty, "Kimathi will never die" the woman said. "But of course if you people have killed him, go and show us his grave! She said this in a strange tone of voice, between defiance and bitterness, and for a minute we all kept quiet." (Preface, The Trial of Dedan Kimathi)

The Africans refused to accept Kimathi's death. To them, Kimathi resembles armed-resistance, and by refusing his death, they announce the continuity of their armed-resistance until they gain their freedom. The execution of Kimathi was purposely made by the colonizer to stop the native's resistance, but what had happened is the opposite, the announcement of his death was the starting point of a new phase of revolution.

Fanon confirms that "colonialism is an instrument of systematic dehumanization" (1963:53). Through discursive and violent measures, it strives to undermine, degrade and limit the colonized people's sense of their own humanity once they have internalized their prescribed inferiority, they will accept domination. That is why, in The Trial of Dedan Kimathi, Kimathi keeps encouraging his people to rebel against the imperial powers and to continue their revolution until independence. He addresses the crowd in the court:

So, go

Organize in your homes

Organize in the mountains....

Uproot from you those

Who are selling out to imperialism?

Kenyan masses shall be free! (1976:84)

Contrary to Said, Fanon expected his call to arms which would undo the damage, especially the psychological and moral damage, which the colonial apparatus wrought on the colonized. The colonized who suffered from the bad influence of colonization for a long period of time will be in need to rebuild himself again. Sartre, in his preface to The Wretched of the Earth (1963) argues that "European humanism is nothing but an ideology of lies; a perfect justification of pillage; its honeyed words and its affection of sensibility were only alibis for our aggression" (21). He laments that "with us Europeans, there is nothing more consistent than a racist humanism since the European has only been able to become a man through creating slaves and monsters" (22). In a similar manner, Said notes that "behind the white man's mask of amiable leadership there is always the express willingness to use force, to kill and be killed." (1978:226)

Kimathi exposed the hypocrisy of the imperial powers. One can hear Kimathi warning his people against the imperial powers and showing his hostility to the oppressor:

Judge: $\quad$ Kimathi s/o Wachiuri, you have been found guilty of possessing a fire arm which was found in your person at or near Ihururu on the night of October the $21^{\text {st }}$, contrary to special emergency regulations. Have you anything to say before you sentence?

Kimathi: In the court of imperialism! 
There has never and will never be justice for the people

Under imperialism.

Justice is created through a revolutionary struggle against all the forces of imperialism. (1976:82)

The absence of justice among Africans is one of the ways to underestimate the natives. According to the imperial powers, the natives are not human beings, they are just enslaved blacks. Therefore, there is no reason to be fair with them. And what happened in the court is a kind of sarcastic court to execute Kimathi in front of his people. The colonizer thinks that by the execution of their leader, the colonizer will silence the Africans forever.

As Gikuyu people suffer degradation and torture, Kimathi persists in his rejection of the imperial powers and keeps calling for armed resistance. His enthusiastic speech encourages the crowd in the court, and suddenly "the stage gives way to a mighty crowd of workers and peasants at the center of which are a boy and girl, singing a thunderous freedom song." (1976: 84)

Resistance is an important tool to gain independence The objective of this resistance is the transformation of the political and economic reality of the colonized in an attempt to create a society with a cultural character and political and economic autonomy that confirm its recognition as a human community and an equal society with others as well as reviving the indigenous history and traditions. Resistance is what produces control over people's own destiny and future.

As suggested before, even after independence, countries continued to engage with the imperial experience. In Thiong'o's The Black Hermit, Omange addresses Remi about the political situation in Kenya after independence:

But people have the right to destroy a government, any government that continues the practice of the colonial regime. (1968: 30)

Remi says:

Then, of course, you could go on being destructive, for as a nationalist revolutionary your aim was to discredit the colonial power in the eyes of the people. (30)

Here, the anti-colonial native emerges as an activist for change. Upon him or her falls the responsibility of articulating and theorizing a vision of transformation which stops the colonial system and its domination over land and fortune. Kadiatu Kanneh confirms that "colonialism changes, creates human experience and subjectivity and rearranges the terms of being for both settler and native. The confusion between hatred and desire where resistance is complicated by yearning and imitation is, for Fanon, a central dynamic within anti-colonial struggle." (Gordon et al, 1998: 86)

Of course, with a change in the situation from colonialism to neocolonialism, ways of resistance must also shift from armed resistance aimed in large part at seizing the land, to resisting the dupes and agents of the colonizer and their political agendas in post-independence nations and to the revitalization of culture considerably more ambiguous matters.

Edward Said continues to believe in non-violent resistance, in the power of words to rectify distorted images of the cultural other, and in negotiation with the colonizer. In sharp contrast, Fanon sees violence as the only way to end colonialism, and give the majority the chance to regain their dignity and identity, enjoy their humanity and protect their fortune and their land. Dedan Kimathi called for armed resistance and revolution to free the oppressed people from their enslavement. In the play, Dedan Kimathi, addressing the judge in the court, says:

An imperialist court of law. Death. To a criminal judge, in a criminal court, set up by criminal law, the law of oppression (1976:25).

Further, Kimathi remarks:

This is a new war. We have bled for you. We have fought your wars for you; against the Germans, Japanese and Italians. This time we shall bleed for our soil, for our freedom, until you let go (1976:34).

Kimathi contends that all nations gained their independence by revolution, and evokes the support provided by Africans to British wars against other nations. Now, the time has come for Africans to bleed for their own country. The natives consider the colonizers as cannibals who want to devour their lives and their fortune that cannot be sent out of their country without violence.

Gordon argues that from Fanon's point of view "a colonized person would be poisoned by the toxins of the colonial syndrome, such as low self-esteem, and this violence will help in rehabilitating and healing the poisoned natives, so they can regain their psychological health" (Gordon et al, 1996:284). According to Fanon, most of the time, the 
call for non-violent resistance comes from the bourgeoisie, since it has the same interests as the colonizer.

On the other hand, Barbara Deming, in her essay "On Revolution and Equilibrium" (1971), goes against violent social change and challenges Fanon on what she sees as his overdependence on violence. Deming suggests that nonviolent methods will cause less effect on people, the colonized and the colonizer. According to her, many people will die in the case of violent resistance; whereas, less people will die in the case of non-violence resistance. What Deming cares about is humanity, as she does not want people to die, she wants them to follow the nonviolence path. Also, Deming wants them to defend themselves to refuse colonialism and to stay alive, and she does not want to harm any human being. Deming pities both the colonized and the colonizer.

The Trial of Dedan Kimathi castigates those who want to negotiate with the imperial powers at a critical moment. Kimathi says: "There are others: Those who went to negotiate, with the enemy despite the ban on talks at this stage of our struggle." (1976:70) Kimathi criticizes the natives who accept to negotiate with the imperial powers. According to Kimathi, those people just look for their own interest regardless of the interest of their people and their country. Kimathi accuses them of betraying their country and their people too.

They accuse those who agree to negotiate with the colonizer of betraying their people and of being concerned only with their own benefits where these negotiations will help protect the interests of the colonizers; and that their people may experience harm. The peasants, who are suffering from political oppression and a horrible economic situation, refuse this peaceful resistance and call for violent resistance. Fanon remarks in The Wretched of the Earth that:

It is clear that in the colonial countries the peasants alone are revolutionary, for they have nothing to lose and everything to gain. The starving peasant outside the class system is the first among the exploited to discover that only violence pays. For him, there is no compromise; no possible coming to terms; colonization or decolonization is simply a question of relative strength. (1963:84)

Sartre, in the preface of The Wretched of the Earth "denaturalizes the conceptual category of native and exposes its historicity and its discursively constructed and imposed nature, in opposition to the equally constructed category of settler: The status of native is a nervous condition introduced and maintained by the settler among colonized people with their consent" (1963:17).

On the basis of all this, Fanon concludes that "colonialism is not a thinking machine nor a body endowed with reasoning faculties. It is violence in its natural state, and it will only yield when confronted with greater violence" (Fanon, 1963: 84). As colonial-discursive categories break down, the natives discover that the colonizer is merely a human being and has the same fears and feelings like they do. In The Trial of Dedan Kimathi, an African woman addresses a solider: "Imagine. I would have never believed it. A white man. A solider. Afraid" (1976: 10). Indeed, the colonizer has the same psychological disorder as the colonized, stemming from the same source: colonization. Guilt and fear of violence and losing their privileged place dehumanize the colonizers just as Africans dehumanized, and only the end of colonialism and their return to their societies can help them.

The Trial of Dedan Kimathi is concerned with giving the subaltern back their liberty and their voice. The silent black native presented in so many colonial texts does not any more exist; indeed, in Trial of Dedan Kimathi, Africans are given a louder voice than that of the colonizer, drowning out the colonial judge. Landry and Maclean explain that" the agency of change is located in the insurgent or the subaltern" (1996: 205). Therefore, without the revolution of the masses of peasants, nothing will be changed. Kimathi points to the sufferings of his people under the domination of the imperial powers, and how the greed of the colonizer exploits the African people, land and fortune. Kimathi urges his people, the Africans, to fight, and to resist the hegemony of the colonizer. He inspires his people to struggle till they gain freedom. He says:

Kimathi: What have they done for our people? What? Protected the oppressor. Licensed the murderers of the people: our people,

Whipped when they didn't pick your tea leaves.

...that is the eternal law of the oppressed,

Of the humiliated, of the injured, the insulted!

Fight

Struggle

Change. (1976, 26-27)

The colonizers want to enslave all of the natives and torture them to death in order to inherit an empty land. The 
colonizer humiliates the African, who is killed when he resists and whipped when he does not; those are his only alternatives. Kimathi says:

Imprisoned when they refused to "ayah" your babies, and boy your houses and gardens. Murdered when they did not rickshaw your ladies and gentlemen. (27)

The Trial of Dedan Kimathi is different from that of Nelson Mandela. Mandela was an advocate who defended himself in front of the court, and wondered "do you think that there is justice for a black man in the court of whites" (Source is needed here). The judge sentenced Mandela with life-long imprisonment instead of death to prove to the world that there was justice in a white court. In contrast, Kimathi was sentenced to death, motivating the colonized people to continue their revolution. In The Trial of Dedan Kimathi, in court, one of the settlers points his gun towards Kimathi as he is whisked out of the court, screaming at the top of his voice: "Bloody bastard Mau Mau. I will shoot you together with that communist. Listen, you will die now" (1976:30).

\section{Conclusion}

In a nutshell, this article has raised the question of, whether postcolonial theory succeeded in deconstructing the hierarchies and erasing the boundaries between the colonizer and the colonized that were built before. Do the counter-narratives, which have been written after the end of colonialism, reflect the new Africa, or are they just a kind of response to an appalling request that comes out from some governmental powers for a specific reason? What we are sure about is that negotiations and freedom seem doomed in these works to lead to a reassertion of domination and that only revolution can grasp freedom.

In the contemporary postcolonial debate, armed resistance appears as the only solution for occupied people to regain their freedom and their humanity. Upon all of the thinkers falls the responsibility of articulating and theorizing a vision of transformation which stops the colonial apparatus, fixes the problems it passes down to the colonized and creates a new balanced human community.

This article concluded that the oppressed will find no space for negotiation unless the oppressors change their approach, which will never happen as long as the colonizers are convinced of their superiority and the inferiority of the colonized. Yet, we still wonder whether postcolonial theory succeeded in deconstructing the literary texts that have been written during the colonial period, and we keep wondering if this theory helped the Africans narrate their own stories in a different way.

The Trial of Dedan Kimathi proved that nothing will free the colonized land except revolution. According to Kimathi, nothing will give the Africans their freedom back except armed resistance. Negotiations with the colonizer appeared as a kind of betrayal to the country. In the Black Hermit, Remi could not find the right path in which two cultures can meet peacefully. The colonizer's imposed culture tries to erase the rooted African culture; therefore, the clash between these two cultures will never come to an end.

\section{References}

Arinto, B. P. (1991). Women and Revolution: The Poetry of Resistance of Latin American Women Writers. Review of Women's Studies. UP Center for Women's Studies, 11(2), 59.

Ashcroft, B. G., \& Helen T. (1989). The Empire Writes Back. London: Routledge.

Bhaba, H. (1994). The Location of Culture. New York: Routledge.

Coulthard, G. (2006). Subjects of Empire: Indigenous Peoples and the Politics of Recognition in Colonial Contexts. Contemporary Political Theory, 6, 437-460.

Deming, B. (1971). Revolution and Equilibrium. New York: Grossman Publishers.

Eagleton, T. (2000). The Idea of Culture. Oxford: Blackwell.

Eid, H. (2000). Naipaul's A Bend in the River and Neocolonialism as comparative context. Comparative Literature Culture Journal, 2(3).

Fanon, F. (1963). The Wretched of the Earth. New York: Grove Press.

Fanon, F. (1986). Black Skin White Masks. (First published 1952). United Kingdom: Pluto.

Gordon, L., Whiting, T. A., \& White, R. (Eds.). (1996). Fanon A Critical Reader. Massachusetts: Blackwell Publishers Inc.

Hall, S., \& Paul du Gay (Eds.) (1996). Questions of Cultural Identity. London: Sage.

Harlow, B. (1987). Resistance Literature. London. New York: Routledge. 
Jeffferess, D. (2008). Postcolonial Resistance: Culture, Liberation, and Transformation. Toronto. Buffalo. London: University of Toronto Press.

K., Vladimir. R., K. F., \& Zima, P. (1976). Black Africa: Literature and Language. Dordrecht: Riedell.

Mboukou, M. J. P. (1965). Black African Literature. Washington: D.C Black Orpheus Press.

Ngugi, W. T (1968). The Black Hermit. Nairobi: Print Well Industries.

Ngugi, W. T., \& Micere, M. (1976). The Trial of Dedan Kimathi. Salt Lake City: Sunlitho.

Ngugi, W. T. (1986). The Politics of Language in African Literature: Decolonizing the Mind. Nairobi: James Currey.

Ngugi, W. T. (1993). Moving the Center: The struggle for Cultural Freedoms. London: Closet Private.

Resistance, Discourse of Colonialism and Clash of Cultures in Modern African Drama, Unpublished Ph.D. Thesis, University of Jordan, 2018.

Said, E. (1992). Culture and Imperialism. New York: Routledge.

Said, E. (1978). Orientalism. London: Routledge.

Sartre, J. P. (1963). Preface. In: Frantz Fanon. The Wretched of the Earth. (Trans)Constance Farrington (pp. 7-26). New York: Grove Press.

Williams, R. (1987). Culture and Society: Coleridge to Orwell. London: Hogarth Press.

Young, R. J. C. (1995). Colonial Desire: Hybridity in Theory, Culture and Race. London: Routledge.

\section{Copyrights}

Copyright for this article is retained by the author(s), with first publication rights granted to the journal.

This is an open-access article distributed under the terms and conditions of the Creative Commons Attribution license (http://creativecommons.org/licenses/by/4.0/). 